\title{
The effects of science, technology, society, environment (STSE) interactions on teaching chemistry
}

\author{
Nuray Yörük ${ }^{1^{*}}$, Inci Morgil ${ }^{2}$, Nilgün Seçken ${ }^{2}$ \\ ${ }^{1}$ Ministry of National Education, Ankara, Türkiye; * Corresponding Author: nurayyoruk@yahoo.com \\ ${ }^{2}$ Hacettepe University, Chemistry Education, Ankara, Türkiye
}

Received 14 September 2010; revised 15 October 2010; accepted 18 October 2010.

\section{ABSTRACT}

This study aimed to investigate the effects of making Science, Technology, Society and Environment relations on students' comprehension of chemistry topics through teaching chemistry using STSE approach at secondary level. The study made use of the research model where pre and post tests were administered to control and treatment groups. The Chemistry Achievement Test (CAT) was used in the study. The sampling consisted of Grade 9 students studying at Anatolian High School and Vocational High School. Since the sampling had not been equated, in order to determine students' logical and spatial thinking skills, they were administered Logical Thinking Skill Test and Mental Rotation test as pretests. Students were chosen randomly to take part in two control and two treatment groups. This experimental study was applied to the treatment group in teaching of "Separation of Mixtures" topic in Grade 9 Chemistry course during a four-week period. Students in the control group were taught through the traditional teaching methods. The data obtained were analyzed through the SPSS Software. As a result of the study, statistically significant increases were observed in the achievement levels of treatment group which received instruction using STSE relations. The change observed in the achievement levels of the control group was not statistically significant. The difference between the achievement levels of control and treatment groups in the posttests were favoring the treatment groups.

Keywords: Science; Technology; Society; Environment (STSE); Chemistry Education; Separation of Mixtures

\section{INTRODUCTION}

In order a country to take steps towards being an information society, changes need to be made in the learning environments. Society consists of individuals and information is communicated through individuals. Improvement in science would affect technology, society and environment positively or negatively. Science could develop as a result of an interaction between technology as the application of theoretical knowledge and requirements created by social needs. The effects of this improvement have also reflected on the teaching of science related courses. The most appropriate educational philosophy that responds to these studies could be explained by the STSE approach.

STSE stems from the belief that a connection between the student and the real world should be established. This process would lead the student to recognize possible problems that $\mathrm{s} / \mathrm{he}$ has. An environment is created, where students could collect data for the solution of their problems, consider alternative solution ways, determine the best ways to solve the problem and practice them [1].

Chemistry is a field of science, which investigates the nature and behaviors of all substances in the universe and uses this information to address the needs of humanity as well as establishing an environment of peace and welfare [2]. Many situations we come across in life are closely related to chemistry and involve scientific knowledge. As individuals comprehend the relationship between what they learn at school and what events affect their lives, this could contribute to improvement of their scientific literacy. Unless this relationship is comprehended at schools, individuals could not attain the required knowledge or skills for an easier life. Shortly, in order individuals to understand and comprehend the technological developments that affect all aspects of our lives, they should receive training in basic science course. That is how individuals could see the importance of science and develop positive attitude towards it. With the help of STSE related science education, students 
recognize the effects of technology in social life. Moreover, by understanding the relationship between science, technology, society and environment, students could recognize the interaction among the four.

Why are STSE relations required in science education?

Human history experienced the process of moving towards being an information society with the invention of the first programmable computer in 1946, the ENIAC [3]. These improvements in computer and communication technologies increased the production of knowledge and its transfer. This was enabled by the ability of information technologies to maximize the level of communication and sharing between individuals and organizations. These developments bring forward the question that how developments in communication and sharing of knowledge could be integrated into education. Unless the rapidly developing technology is applied to the field of education, students would stay far behind the modern age at the school environment. Information is rapidly changing and increasing in quantity. In this case, it is more important for students to learn how they could acquire and use knowledge rather than memorizing it directly. Therefore, they should be aware of how science courses they take at school could be related to technology and society in terms of their uses.

"What is STSE and how could it be defined?"

Although STSE seems to be taken as easy since it resembles similar topics to all individuals, its definition and depth are quite different. The aim of the STSE related courses aim to enable individuals to understand science better, to encourage students with creativity and critical thinking, and to make boring and abstract topics more interesting and fun [4]. There is no doubt that learning could never be actualized in an isolated environment from the world [5]. On the other hand, science topics have been taught far away from the realities of the real world. With the help of STSE relations, students are aimed to construct their own understanding of STSE concepts by uniting their life experiences with natural world in terms of science and human made world in terms of technology. Individuals are expected to construct and relate these STSE concepts considering his/her continuous interaction [4].

A study by Roy in 2000 concluded that:

1) Students would have knowledge about certain topics related to science and technology with an increased awareness level;

2) Students would be able to analyze topics related to science and technology;

3) Technology would affect social life and there would be an interaction with technology;

4) Students, having received training in science, would prefer to study further in science or any related field they may be interested in [6].

STSE related courses mediate in overcoming the misunderstandings about science by considering the role of science in the society. The main aim of the courses related to science is to present science and technology as a methodology, which enables students to make best determinations through comparing scientific advantages and disadvantages that appear as results of scientific developments while trying to solve problems they face.

It is a part of STSE components to know the required applications in life and solve the social problems through science and technology. Teaching using this approach would result in an increase in students' scientific literacy and interest. By enabling the student to recognize the interaction among STSE, this approach would facilitate making abstract concepts concrete.

STSE related education came from the postmodernist approach [7-9]. This approach defines science as scientific studies within human power, social, political and economical content rather than theories and observable findings $[10,11]$.

STSE studies in the education system have been made in different countries under various titles. This was mainly a result of different countries' having various cultural, traditional and conceptual backgrounds. It would be difficult to say that STSE related teaching program would end up with same conclusions in every country without any additions or integrations. The different titles given to the same approach could be explained through the individual requirements of each country. For instance, there is specifically important emphasis on environment within STS scope in Canada $[4,10,12,13,14]$. These studies concluded with the addition of "environment" to STS, which later became STSE. In Belgium, STS was enhanced with the involvement of "ethics" and the term became STES relations with the publication of the periodical named "Science, Technology, Ethics and Society" [9], "Science, technology and citizenship" [15], "Nature, technology, society" [16], "Science for Society Approach" [17], "Functional Science Literacy" [18], "Social Awareness" [19], are other examples of this approach under different titles in the literature. The common aim of all these studies was to develop the scientific literacy and scientific understanding. The target should be science for everyone and STSE should function as the tool in science courses. After 1985, it is observed that studies on this approach have increased in number. These studies also took place in projects such as the PLON [20] in Holland, the SISCON [21] in England, and the AAAS [22] in the USA. While these developments were happening in the world, Turkey met the STS related teaching in the study called "Elementary 
Science Education" in 1997; a study ran by Turkish Higher Education Institution and the World Bank. In $2004,4^{\text {th }}$ and $5^{\text {th }}$ grade elementary science curriculum were changed and in $2005,6^{\text {th }}, 7^{\text {th }}$ and $8^{\text {th }}$ grade curriculum were updated as changing the name of the course as Science and Technology and including STSE attainments among the content attainments [23,24].

The changes in the chemistry curriculum in Turkey had been limited to structural modifications since 1985 . The need for a modern chemistry curriculum was addressed by the Ministry of National Education in 2007 with the preparation of the new chemistry curriculum, which has been in use since the 2008-2009 academic year. The recent curriculum involves STSE relations as Chemistry, Technology, Society and Environment (CTSE) [25]. The CTSE related attainments are listed as items in Chemistry Curriculum, where they are classified in general. There are no connections between the content attainments and CTSE attainments; therefore, they are presented independently. The teaching program requires the teacher's presentation of attainments by establishing connections between the content attainments and CTSE attainments.

Apart from the projects, other studies have shown that students presented more positive attitudes towards STSE and STS approaches, which were also effective in making connections related to the course [6,26-34].

This study aims to compare the Chemistry Achievement Test scores of students from different educational institutions (Anatolian High School, Vocational High School), who experienced teaching of chemistry within the STSE approach. In Turkey, STSE approach has not yet been applied in the chemistry course in different secondary schools. Therefore, this study is expected to contribute to the literature with its findings.

The reason for the choice of two different secondary level educational institutions could be explained as follows: Grade 9 students, who are 15 years old, experience the challenge of adapting to a secondary level institution and learning different courses at the same time. These students try to shape their future within the secondary level educational institution they have chosen while gaining consciousness levels limited to what is provided for them by their parents and environments. Students of the Anatolian High and Vocational High schools come from families with various socio-cultural and economical backgrounds. Each student at the Anatolian High or Vocational High schools has a different scope of previously learnt knowledge because of the opportunities having been provided for them by their families. Therefore, the groups constructed from the students of Anatolian High and Vocational High Schools reflect the general student profile of the country. In order the findings of this study to be generalized to the real life, schools from different districts and students from different educational institutions were chosen. Therefore, the study was conducted with a sampling group that reflected the Grade 9 students in general.

\section{MATERIAL AND METHODS}

This section of the paper presents information related to the research model, sampling, data collection tool and analysis of the data.

The study involved the application of the following procedures to the Grade 9 students studying at different secondary level educational institutions (Anatolian High School and Vocational High School). Students from Grade 9 were chosen randomly and two classes were classified in both schools as control and treatment groups.

In order not to classify students randomly, all students in both groups were administered logical Thinking Skill Test (LTST), Mental Rotation Test (MRT) and Chemistry Achievement Test (CAT) in order to asses their previously learnt knowledge, logical thinking skills and spatial thinking skills. The Chemistry Achievement Test was later administered as the posttest in order to compare the findings from the control group, who were taught in the traditional ways, and the treatment group, who were taught according to the STSE approach on the topic of "Separating Mixtures". In order to provide the external reliability of the study and in order to avoid the effects of proficiency levels on the findings, a total of four classes were assigned in two different types of secondary level educational institutions. By forming control and treatment groups in two different school types, researcher's subjectivity and student interaction effects were overcome, which lead to the focus on the effects of STSE related chemistry education on conceptual achievement and comprehension levels.

After LTST, MRT and CAT were administered as pretests, teaching methodologies wee randomly chosen for groups. Separating Mixtures was taught to the control group in the traditional teaching methodology. Treatment group was taught by the researcher through the STSE related education. The content was prepared in line with the curriculum and the same content was taught to the treatment group through STSE related teaching methodology whereas the control group was taught in the traditional way.

1) All students in control and treatment groups were administered the Logical Thinking Skills Test, which was developed by Tobin and Capie [35] and translated into Turkish by Geban, Askar and Özkan, [36]. The test consisted of 10 questions.

2) All students were administered the Mental Rotation 
Test, which was developed by Bodner and Guay [37] and was translated in to Turkish by Kavak [38]. The test consisted of 20 questions.

3) The Chemistry Achievement Test that was developed in order to assess whether students learned the concepts related to Separating Mixtures topic and it consisted of 35 questions. The test was prepared according to the opinions of experienced teachers and academic staff. The validity of the test, which is defined as the content validity, was evaluated to be high by three specialist academic staff. The reliability of the test was commented with $\alpha$ reliability coefficient. Before it was used in the study, the test was administrated to 90 high school students and $\alpha$ reliability coefficient was calculated to be 0.87 . This test was administered as pre and posttests.

The dependent variable of the study was the achievement scores students received from CAT on Separation of Mixtures.

The independent variables were the STSE related teaching methodology administered to the treatment group and the traditional method administered to the control group.

The variables taken under control are the previous knowledge of students assessed by the CAT, their logical thinking skills assessed by the LTST and spatial thinking skills assessed by the Mental Rotation Test.

\subsection{Sampling}

This study was administered to Grade 9 students of an Anatolian High School and a Vocational High School in Ankara authorized by the Ministry of National Education.

The treatment group of the vocational high school consisted of 33 students and its control group was formed by 30 students. In Anatolian high school, there were 28 students in the treatment group and 28 students in the control group.

\subsection{Data Collection Tool}

In the treatment groups of both high schools, Separation of Mixtures was taught according to the STSE related chemistry teaching methodology. As Table 1, Table 2, Table 3 and Table 4 display, the study lasted for four weeks. The other two groups, assigned as control groups, received traditional instruction on the same topic.

\subsection{Analysis of the Data}

Chemistry lessons were taught through making connections with the STSE topics. In order to determine the effects of STSE related chemistry education approach on students' achievement levels, the data obtained from CAT were statistically evaluated via the covariance analysis.

Table 1. STSE related chemistry education administered to the treatment group - 1 st week.

\begin{tabular}{ll}
\hline STSE topics & Recycling metal wastes. Security precautions for petrol containers. \\
Content/Titles & Separating Mixtures Separation via the Magnet Separation via electrification \\
Teaching and learning approaches & $\begin{array}{l}\text { Small group research, watching movies, questioning-based learning, laboratory prac- } \\
\text { tice, data analysis, simulations, concept maps, making models. }\end{array}$ \\
Student skills & $\begin{array}{l}\text { Asking questions, evaluating technological topics, making decisions, valuing the given } \\
\text { decision. }\end{array}$ \\
Concepts & Mixture, Separation Techniques, Homogenous mixtures, Heterogeneous mixtures. \\
\hline
\end{tabular}

Table 2. STSE related chemistry education administered to the treatment group - 2 nd week.

\begin{tabular}{ll}
\hline STSE topics & $\begin{array}{l}\text { Separating salt from the sea water dialysis, obtaining carotene. } \\
\text { Separation through density difference (Explores the methods that make use of density } \\
\text { differences in separating substances from each other) separation through filtration } \\
\text { (Explains separation made by making use of the particle size differences.) Separation } \\
\text { through solubility difference (Notices that solubility differences aid in separating sub- } \\
\text { stances) }\end{array}$ \\
Content/Titles & $\begin{array}{l}\text { Brainstorming, asking questions, classroom discussions, questioning-based learning, } \\
\text { role playing, simulations. }\end{array}$ \\
Teaching and learning approaches & $\begin{array}{l}\text { Data analysis, interdisciplinary problem solving, evaluating technological topics, ques- } \\
\text { tioning for decision making. }\end{array}$ \\
Colvent, Solution, Solubility, Corrosion, Floatation, Vaporization crystallization, Di- \\
alysis, Decantation.
\end{tabular}


Table 3. STSE related chemistry education administered to the treatment group - 3 rd week.

\begin{tabular}{ll}
\hline STSE topics & $\begin{array}{l}\text { Separating metals from ores. Obtaining medicine and alcoholic beverages from plants } \\
\text { through fractionation obtaining perfumes. } \\
\text { Separation through heat differences when changing state. (Boiling heat differences) }\end{array}$ \\
Exemplifies separation by making use of the differences between the boiling points. \\
(Melting heat differences) Examplifies separation by making use of the differences \\
between the melting points.
\end{tabular}

Table 4. STSE related chemistry education administered to the treatment group - 4th week.

\begin{tabular}{ll}
\hline STSE topics & Making connections among the STSE topics. \\
Content/Titles & Suggests appropriate separation methods fro the given mixtures. \\
Teaching and learning approaches & All approaches made use of during the course of the lesson. \\
Student skills & All skills attained during the course of the lesson. \\
Concepts & All concepts learnt during the course of the lesson. \\
\hline
\end{tabular}

\section{CONCLUSIONS}

Due to the aim of the study that was determining any possible changes in the chemistry achievement levels of students as a result of the administered teaching methodology, the spatial thinking skills and mental rotation skills of students were assessed via MRT and LTST. The results of these tests were taken as covariance to be made use of in the other applications or statistical evaluations.

CAT was administered as the pretest in order to determine the equivalence of the groups since the treatment groups in both schools were going to be taught according to the STSE relations. The reason for this act was to determine whether the chosen groups were at the same level in terms of chemistry knowledge regarding the chosen topic.

The pretest CAT results were compared using ANCOVA. Before the covariance analysis, the variances were tested in terms of their being homogenous and the appropriateness of the curve between the dependent variable and the covariance.

- The covariance analysis results of the evaluation made on the CAT pre and posttest results of the Vocational High School students.

The CAT pretest average of the treatment group was 9.97 and the Cat pretest results of the control group was 13.46. This result is statistically significant favoring the control group $(p=0.014)$, which made it eligible for the study.
The posttest CAT data evaluation concluded with the covariance analysis results that displayed an average of 13.30 for the treatment group and 14.87 for the control group. Although there has been quite an increase in the average score of the treatment group, the difference between the treatment and control group averages are not significant $(\mathrm{p}=0.230)$.

- The covariance analysis results of the evaluation made on the CAT pre and posttest results of the Anatolian High School students.

The CAT pretest average score of the treatment group was found to be 21.82 and that of the control group was found to be 24.08. Although the average of the control group is rather high, the difference between the average scores of the treatment and control groups is not statistically significant $(\mathrm{p}=0.051)$.

According to the covariance analysis results of the posttest CAT, the treatment group's average score was 27.43; the average score for the control group was 23.71 . The treatment group, which was taught within the STSE related teaching approach, displayed an important increase in their average scores and this difference is statistically significant $(p=0.003)$.

- The comparison of pre and posttest Average Scores of Control and Treatment groups:

The changes in the average scores of control and treatment groups both for pre and posttests were evaluated through the dependent t-test and the results are displayed on Table 5. 
Table 5. The Results of the Dependent variable T-test, which was administered in order to compare the CAT pre and posttest scores of the treatment groups at both Vocational and Anatolian High Schools.

\begin{tabular}{lccc}
\hline & Pretest & Posttest & Significance \\
\hline Vocational High School & 13.43 & 13.93 & 0.518 \\
Anatolian High School & 23.75 & 22.14 & 0.193 \\
\hline
\end{tabular}

Table 6 displays that there were significant increases in both control groups at the end of the application. Looking at these results, STSE approach could be identified as a productive teaching methodology for students as the increase in the achievement levels of the treatment groups were observed to be higher.

\section{DISCUSSION AND SUGGESTIONS}

The findings in the literature are supportive of the conclusions that have been come to in this study that achievement levels in chemistry could be increased through teaching via the STSE related teaching approach. The results of this study are in line with Yager's study in 1994, where he evaluated the effectiveness of the STSE related teaching approach [32]. Students, having recognized their own skills with the help of the approach, have learnt the topics more meaningfully than the students, who receive teaching through traditional methodologies. In practice, students, who receive education within the STSE related teaching approach, are more competent in relating new situations and concepts.

Another striking point of this study is the two different types of schools chosen as grounds. In Turkey, Anatolian High Schools require a placement test score for enrollment. Students could register to these schools in case they score above average in a central placement test. On the other hand, while vocational high schools do not have such requirements, their students experience a score disadvantage in the university placement, and this leads to a conclusion that students do not prefer to study at vocational high schools. As the pretest average scores display, students of Anatolian High Schools achieve better than students of the vocational high schools. Fortunately, teaching through STSE related approach concluded with an increase in the achievement scores of the treatment groups in both types of schools. In other words, the choice of STSE related teaching methodology would contribute to the achievement levels of vocational high school students, where the expected university placement average is rather low.

STSE related teaching enables students to make more connections with the topics, which increases the interaction during the lesson and creates a student-centered
Table 6. The Results of the Dependent variable T-test, which was administered in order to compare the CAT pre and posttest scores of the control groups at both Vocational and Anatolian High Schools.

\begin{tabular}{lccc}
\hline & Pretest & Posttest & Significance \\
\hline Vocational High School & 10.00 & 14.18 & 0.000 \\
Anatolian High School & 23.68 & 27.46 & 0.000 \\
\hline
\end{tabular}

learning environment. This is a natural result of STSE related teaching practice. Students, therefore, get involved in the research process themselves, while trying to make connections with the concepts and topics.

This study concluded that, as students made connections between what they learn and what they experience in the real life through STSE connections, their attention to the lesson was also affected positively. Most of the students do not get interested in chemistry because the course is not taught in an attractive way. Therefore, students do not have positive attitudes towards a course that they do not get interested in. the disconnection between what students learn and what they experience in the real life decreases their level of interest in the lesson and destroys the bridge between the student and science education. In order to create more interest in students, STSE related teaching should be considered and improved.

It was determined that STSE related teaching applied in developed countries resulted in different ways than the applications in other countries. Therefore, in case a well-qualified curriculum is to be administered in another country, it should be adopted to the country's culture. The recent studies on Chemistry curriculum should take these into account in such a way to present the content attainments through making connections with STSE related topics.

The content of the Chemistry course should enable individuals to attain the adequate knowledge to live in the modern technological environment. STSE relations should allow students to recognize their environment and technological condition, understand their contributions to the society and predict the possible damages that could happen. Therefore, studies should be conducted in order to prepare the teachers and equipments, which could enable students to make STSE connections.

This study should not be limited to the Separation of Mixtures as a topic of Chemistry, and should be applied to their topics within the teaching program to research on its effectiveness through different activities.

Within STSE related teaching sessions, by using the interviewing method, students' opinions about STSE concepts could be examined more deeply.

Teachers, in countries where STSE related teaching is 
applied, are obliged to follow the changes and enhancements in order to make connections with different topics. Teachers tend to avoid using STSE related teaching as it requires a separate preparation process for the lesson in terms of making connections. Before the STSE related science education is administered, teachers should be acknowledged about the system. Secondary level chemistry teachers should be informed more about STSE approach. Considering the requirements of teachers for understanding and getting prepared for the approach, in-service training programs could be organized involving a similar study with the teachers.

Students, who do not prefer to get training in science related tracks, could be taken as sampling and observations could be made on them to assess the effectiveness of STSE related teaching.

Apart from teaching, STSE related science education also differentiates the assessment methods. Therefore, traditional assessment and evaluation techniques could be enriched with alternative techniques, which could be the focus of another study. This could be suggested as an area for further research.

\section{REFERENCES}

[1] Yager, R.E. (1990) The science/technology/society movement in the United States: Its origin, evolution, and rationale. Social Education, 54, 198-200.

[2] Atasoy, B. (2004) Basic Chemistry Concepts, Asil Publishing and Distribution, Ankara, Turkey.

[3] Barutçugil, İ. (2002) Information Management, Kariyer Publishing, İstanbul, Turkey.

[4] Aikenhead, G.S. (1994) What is STS science teaching? In: Solomon, J. and Aikenhead, G.S. Ed., STS Education International Perspectives on Reform, Teacher's College Press, New York.

[5] Nakleh, M.B. (1992) Why some students don't learn chemistry. Journal of Chemical Education, 69, 191- 216.

[6] Roy, R. (2000) Real science education: replacing, "PCB" with s(cience) through STS throughout all levels of K-12, technology and society. Science, Technology, and Society: A Sourcebook on Research and Practice, Kluwer Academic/Pleum Publishers, New York.

[7] Fensham, P.J. (1985) Science for all. Journal of Curriculum Studies, 17, 415-435.

[8] Pedretti, E. (1997) Septic tank crisis: a case study of science, technology and society education in an elementary school. International Journal of Science Education, 19, 1211-1230.

[9] Aikenhead, G.S. (2003) STS Education: A rose by any other name. A Vision for Science Education: Responding to the World of Peter J. Fensham, Routledge Press, Canada.

[10] Solomon, J. (1993) Teaching Science, Technology \& Society. Open University Press, Philadelphia, CA.

[11] Bingle, W. and Gaskell, P. (1994) Science literacy for decision making and the social construction of scientific knowledge. Science Education, 78, 185-201.
[12] Council of Ministry of Education Canada (1997) Common framework of science learning outcomes K-12, Council of Ministers of Education, Canada.

[13] Kumar, D. and Chubin, D. (2000) Science technology and society: A sourcebook or research and practice, Kluwer Academic, London.

[14] Pedretti, E. (2005) STSE education: Principles and practices. In: Aslop, S., Bencze, L., Pedretti, E. Eds. Analysing Exemplary Science Teaching: Theoretical Lenses and a Spectrum of Possibilities for Practice, Open University Press, Mc Graw-Hill Education.

[15] Solomon, J. and Thomas, J. (1999) Science education for the public understanding of science. Studies in Science Education, 33, 61-90.

[16] Andersson, B. (2000) National evaluation for the improvement of science teaching, improving science education: The contribution of research. Open University Press, Birmingham, UK, 62-78.

[17] Osborne, J., Duschl, R. and Fairbrother, B. (2003) Breaking the mould? Teaching science for public understanding: Lessons from the classroom. The Annual Meeting of the National Association for Research in Science Teaching, Philedelphia.

[18] Ryder, J. (2001) Identifying science understanding for functional scientific literacy. Studies in Science Education, 36, 1-42.

[19] Solomon, J. (2003) The UK and the moment for science, technology and society education. A Vision for Science Education: Responding to the work of Peter Fensham, Routletge Falmer, New York, 76-90.

[20] PLON (1984) Ioniserende Straling. Utrecht: Rijksuniversiteit Utrecht, Vakgroep Natuurkunde-Didactiek. Ionizing Radiation (1988), Faculty of Education, Monash University.

[21] SISCON (1983) Science in Social Context in Schools, Oxford Blackwell.

[22] AAAS (1989) American Association for the Advancement of Science, Washington, DC. http://www.aaas.org/

[23] Elementary science and technology teaching program and guide, 4th-5th grades (2004) Ministry of National Education, Board of Education and Discipline.

[24] Elementary science and technology teaching program and guide, 6th-8th grades (2005) Ministry of National Education, Board of Education and Discipline.

[25] Grade 9 chemistry, teaching program (2007), Board of Education and Discipline, Ministry of National Education, Ankara.

[26] Aikenhead, G.S. and Ryan, A.G. (1987) High-school graduates beliefs about science-technology-society. I. Methods and issues in monitoring student views. Science Education, 71, 145-161.

[27] Aikenhead, G.S. and Ryan, A.G. (1992). The development of a new instrument: "Views on science-technologysociety" (VOSTS). Science Education, 76, 477-491.

[28] Finson, K.D. and Enochs, L.G. (1987) Student attitudes toward science-technology-society resulting from visitation to a science-technology museum. Journal of Research in Science Teaching, 24, 593-609.

[29] Fleming, R.W. (1987) High-school graduates beliefs about science-technology-society. II. The interaction among science, technology and society. Science Education, 71, 163-186. 
[30] Zoller, U.E., Morely, P., Sandberg, W. and Wolthers (1990) Goal attainment in science-technology-society $(\mathrm{S} / \mathrm{T} / \mathrm{S})$ education and reality: The case of British Columbia. Science Education, 74, 19-36.

[31] Ben-Chaim, D. and Zoller, U. (1991) The STS outlook profiless of Israeli high-schools students and their teachers. International Journal of Science Education, 13, 447-458.

[32] Yager, R., Tamir, P. and Kellerman, L. (1994) Success with STS in life science classrooms, Grades 4-12. The American Biology Teacher, 56, 268-272.

[33] Bradford, C., Ruba, P.A. and Harkness, W.L. (1995) Views about science-technology-society interactions held by college students in general education physics and STS courses. Science Education, 79, 355-373.

[34] Solbes, J. and Vilches, A. (1997) STS interactions and the teaching of physics and chemistry science education Science Education, 81, 377-386.

[35] Tobin, G.K. and Capie, W. (1981) The development and validation of a group test of logical thinking. Educational and Psychological Measurement, 41, 413-423.

[36] Geban, Ö., Aşkar, P. and Özkan (1992) Effects of computer simulated experiment and problem solving approaches on students' learning outcomes at the high school level. Journal of Educational Research, 86, 5-10.

[37] Bodner, G.M., and Guay, R.B. (1997) The purdue visualization of rotations test. The Chemical Educator, 2, $1-17$.

[38] Kavak, N. (2004) The effects of role playing teaching technique on Grade 10 students' conceptual achievement and perceptions within the constructivist. G. U. Education Science Institute, Ankara. 